\title{
MEMAHAMI RELASI KONSEP FUNGSI, BENTUK DAN MAKNA ARSITEKTUR RUMAH TINGGAL MASYARAKAT KOTA PESISIR UTARA DI KAWASAN JAWA TIMUR (Kasus Studi Rumah Tinggal di Kampung Karangturi dan Kampung Sumber Girang, Lasem)
}

\author{
Bachtiar Fauzy ${ }^{1)}$, Antariksa ${ }^{2}$, dan Purnama Salura ${ }^{3)}$ \\ ${ }^{1)}$ Mahasiswa S3 Arsitektur, Program Pascasarjana, Universitas Katolik Parahyangan, Bandung, Indonesia \\ ${ }^{2)}$ Jurusan Arsitektur, Fakultas Teknik, Universitas Brawijaya, Malang, Indonesia \\ 3) Jurusan Arsitektur, Fakultas Teknik, Universitas Katolik Parahyangan, Bandung, Indonesia \\ Email: bachtiarfauzy@yahoo.co.id;mr.antariksa@gmail.com;purnamasalura@yahoo.com
}

\begin{abstract}
ABSTRAK
Arsitektur rumah tinggal di Pecinan Kampung Karangturi-Lasem yang berada di kawasan Pesisir Utara Jawa merupakan arsitektur komunitas etnis Cina yang memiliki karakter gaya arsitektur Cina, fenomena ini diperkuat dengan data masuknya budaya Cina yang berlangsung sejak abad ke-13. Studi ini mengungkap bagaimana memahami relasi konsep fungsi, bentuk dan makna arsitektur rumah tinggal masyarakat kota Pesisir Utara di kawasan Jawa Timur. Kasus studi ini melihat sejauhmana arsitektur rumah tinggal di Kampung Sumber Girang, Lasem sebagai klien dipengaruhi oleh arsitektur rumah tinggal di Kampung Karangturi sebagai patron. Studi ini menggunakan pendekatan metode strukturalisme dan tipomorfologi untuk mengungkap fenomena relasi konsep arsitektur masyarakat kota Pesisir. Hasil studi ini memperlihatkan bahwa untuk memahami relasi konsep fungsi, bentuk dan makna arsitektur pesisir dapat diungkap melalui telaah relasi konsep sikap manusia Jawa dengan tipe fungsi, bentuk dan makna yang melingkupinya, sehingga menghasilkan struktur permukaan dan struktur dalamnya.
\end{abstract}

Kata kunci: Relasi, konsep, fungsi, bentuk, makna, arsitektur, rumah tinggal.

\begin{abstract}
Housing architecture in the Kampong Chinatown Karangturi - Lasem located in the North Coast of Java was the architecture of the Chinese community that had the character of the Chinese architectural style, this phenomenon is reinforced by the data entry of Chinese culture that took place since the 13th century. This study revealed how to understand the concept relation of function, form and meaning of urban housing architecture in the North Coast region of East Java. Case study looked at the extent of housing architecture in the Kampong Sumber Girang, Lasem as clients affected by the housing architecture in Kampung Karangturi as a patron. This study took the method of structuralism and typomorphology approach to unravel the phenomenon of urban coastal architecture concept of relation. The results of this study showed that to understand the concept relations of function, form and meaning of coastal architecture could be determined through the study of Javanese human behavior concept of relation, which at the end revealed the surface structure and deep structures of coastal architecture.
\end{abstract}

Keywords: Relation, concept, function, form, meaning, architectural, housing.

\section{PENGETAHUAN ARSITEKTUR PESISIR}

Berdasarkan perkembangan sejarah arsitektur di Nusantara menunjukkan bahwa sejak dahulu masyarakat Jawa Pesisiran telah membuka diri terhadap pengaruh budaya luar. Terbentuknya budaya Pesisir melalui proses percampuran budaya (akulturasi) diawali dengan masuknya etnis pendatang yang mempunyai budaya berbeda. Kota Pesisir Utara di kawasan Jawa Timur merupakan awal masuknya pendatang asing untuk berdagang. Kota-kota yang berada di kawasan Pesisir utara Jawa Timur, seperti Lasem, Tuban dan Gresik merupakan kota yang memiliki pelabuhan yang pada masanya berfungsi sebagai kawasan perdagangan, sehingga orang-orang Cina, Arab dan Belanda (VOC tahunl602) menggunakan pelabuhan tersebut untuk keperluan berdagang.

Merujuk berdasar sejarah masuknya etnis pendatang di kawasan kota Pesisir, ada tiga etnis yakni: Cina, Arab dan Belanda yang melakukan kegiatan perdagangan serta menetap dalam kurun waktu yang 
cukup lama. Masuknya etnis pendatang ini diduga berlangsung melalui beberapa periode, seperti: Cina sekitar abad ke 13 - 14, Arab pada abad ke 15-16 dan Belanda pada abad ke 16-19 bersamaan dengan berdirinya VOC dan masa koloni Belanda (Lombard 1996).

Pada era tersebut mulai terjadi percampuran unsur-unsur budaya yang membentuk cikal bakal budaya Pesisir. Kawasan kota Pesisir dianggap sebagai daerah yang terbuka bagi pendatang, sehingga memudahkan terjadinya proses pertemuan dan percampuran budaya melalui kegiatan berdagang. Dalam perkembangannya percampuran budaya (Cina, Arab dan Belanda) memberikan pengaruh pada arsitektur masyarakat kota Pesisir yang terwujud dalam berbagai ragam nilai dan bentuk yang didasarkan pada sosok dan wujud arsitekturnya.

Akulturasi berpengaruh pada arsitektur, dengan demikian akulturasi yang terjadi di kawasan masyarakat kota Pesisir utara Jawa juga berpengaruh terhadap proses pembentukan arsitekturnya, khususnya dalam bentuk percampuran tipe bentuk, ragam arsitektur, pola ruang dan tatanannya. Pengetahuan mengenai relasi konsep fungsi, bentuk dan makna arsitektur penting dalam menentukan arah perkembangan arsitektur masyarakat kota Pesisir utara Jawa.

\section{RUANG LINGKUP STUDI}

Studi ini tentang relasi konsep fungsi, bentuk dan makna arsitektur pesisir akan berlandaskan pada faktor-faktor pengaruh, proses keterkaitan dan konteks unsur budaya dan arsitektur yang bersifat deskriptif-analitis dan interpretatif, berlandaskan pada bukti empiris yang ditemukan dalam kasus studi berdasarkan tingkat paparan (exposure) terhadap pengaruh luar, latar belakang budaya dan unsur pembentuk arsitekturnya.

Studi ini dilakukan di kota Pesisir Utara di kawasan Jawa Timur, yakni: Lasem yang merupakan kawasan yang sangat banyak dipengaruhi oleh budaya Cina melalui proses akulturasi budaya, sehingga kawasan ini sangat representatif untuk menjadi kajian. Objek yang diteliti berupa arsitektur rumah tinggal di Pecinan Kampung Karangturi sebagai patron yang mempengaruhi rumah tinggal tradisional etnis Jawa sebagai klien kampung tumbuh mandiri yang berada di kawasan Kampung Jawa Sumber Girang, Lasem. Studi ini ditentukan secara 'purposive' dan dilakukan telaah secara retrospektif diakronis sejauh dimungkinkan berdasarkan catatan empiris lapangan serta dengan membaca dan mendeskripsikan secara mendalam relasi konsep fungsi, bentuk dan makna arsitekturnya.

\section{PEMAHAMAN PESISIR DALAM RANAH BUDAYA DAN ARSITEKTUR}

Pemahaman tentang Pesisir Utara di kawasan Jawa Timur dapat dilakukan melalui pendekatan budaya, budaya yang dimaksud juga berkenaan dengan sejarah panjang kawasan pesisir yang terbentuk melalui proses akulturasi budaya. Konteks budaya menjadi salah satu unsur yang dapat digunakan untuk menelaah adanya fenomena yang terjadi pada komunitas masyarakat Jawa yang ada di kawasan kota Pesisir Utara Jawa.

\section{Ranah Budaya Jawa}

Kebudayaan Jawa merupakan awal dari pola tata laku manusia dan masyarakat Jawa yang terbentuk melalui sejarah panjang berdasarkan pendekatan kultur-historis manusia Jawa. Konsep budaya Jawa sangat sarat dengan nilai-nilai kearifan lokal yang dikenal dengan kearifan Jawa. Nilai-nilai yang dimaksud juga merupakan representasi dari relasi dan sikap manusia Jawa dengan Tuhan, alam, masyarakat/ sosial dan pribadi/individu, sehingga nilai-nilai inilah yang terus dikembangkan oleh masyarakat Jawa menjadi pedoman dalam melakukan kehidupan sehari-hari (Endraswara 2010).

Dalam pemahaman tentang ruang dalam masyarakat Jawa berkembang dari sosok dan wujud yang sederhana sampai kompleks. Dualisme ruang menurut pandangan masyarakat Jawa, seperti kanan - kiri, depan-belakang, atas-bawah, utara-selatan dan lainnya merupakan ekspresi dari sikap dan orientasi ruang. Teori pasangan ini juga tercermin dalam arsitektur dalam wujud bentuk susunan ruang yang simetri berdasarkan hirarki ruangnya (Adimihardja and Purnama 2004).

Ruang pada arsitektur rumah tinggal Jawa merupakan ungkapan dari hakikat penghayatan terhadap kehidupan dan kepercayaan masyarakatnya. Orientasi terhadap sumbu kosmis utara-selatan sedikit banyak berkaitan dengan mitos Ratu Laut Selatan. Mancapat atau susunan 4-5 juga mendasari pola penataan ruang arsitektur rumah tinggal Jawa, baik dalam skala hunian maupun pola kampung secara keseluruhan.

\section{Ranah Budaya Cina}

Budaya Cina merupakan Agama tradisional orang Cina (Tionghoa) bersifat sinkretis yang diturunkan dari tiga ajaran, yakni Konfusius, Taoisme dan Budhisme, yang sangat menonjol dari kegiatan religius mereka adalah penyembahan arwah leluhur 
yang sebenarnya sangat tua menjadi kepercayaan mereka dan kemudian diperkuat oleh ajaran Konfusius. Agama yang sinkretik ini lebih dikenal sebagai kebudayaan Cina. Penyembahan arwah leluhur adalah pemujaan yang mengkontribusi kepada integrasi dan mengekalkan kehadiran leluhur di dalam keluarga sebagai satu unit dasar masyarakat Tionghoa (Pratiwo 2010).

Konsep kosmologi diterjemahkan ke dalam konsep ruang untuk permukiman yang diperuntukkan bagi komunitas masyarakat Cina, sehingga konsep inilah yang menjadi acuan dalam penataan order ruang dan hirarki yang diterjemahkan ke dalam gugus ruang. Orientasi rumah menjadi salah satu ciri yang terekspresi dalam bentukan arsitekturnya. Unsurunsur yang selalu melekat pada budaya Cina adalah unsur yang memberikan gambaran tentang alam (flora dan fauna) serta bentuk-bentuk geometrik yang dipadukan dengan nuansa warna dan teksturnya.

Ruang pada arsitektur rumah tinggal Cina di Jawa didasarkan pada bentuk dan hirarki rumah tinggal Cina di daratan, namun mengalami penyesuaian dengan lokasi dan budaya setempat. Dalam kondisi lengkap terdiri dari 1-2 massa utama dan 2 massa tambahan. Hirarki ditentukan oleh lokasi ruang kepala keluarga dan altar persembahan kepada nenek moyang.

\section{Ranah Budaya Pesisir}

Masyarakat kota Pesisir yang sangat terbuka akan memberikan implikasi pada terbentuknya budaya baru melalui proses akulturasi budaya, budaya-budaya pendatang yang masuk di kawasan kota Pesisir pada akhirnya akan membentuk budaya baru, yang dikenal dengan budaya Pesisir. Budaya masyarakat kota Pesisir merupakan wujud dari pola tata laku dan struktur sosial masyarakat pesisir yang membentuk arsitektur kota Pesisir. Arsitektur kota pesisir memiliki karakteristik spesifik dengan berbagai ragam bentuk paduan dari wujud percampuran budaya pendatang (Cina, Arab dan Belanda) dan budaya Jawa (Pesisir).

Budaya dalam konteks peradaban Pesisir (peradaban daerah pantai) merupakan gambaran adanya aneka ragam budaya yang memiliki prinsip interaksi dinamis atau pergerakan dan kreasi aktif heterogenitas dengan adanya kemiripan kultural tentang gambaran mata rantai perdagangan, pergaulan sosial, hubungan politik serta interaksi kesusasteraan dan kesenian (Vickers 2009).

Untuk mengungkap fenomena arsitektur masyarakat kota Pesisir Utara Jawa, maka perlu diuraikan teori yang memberikan pengaruh signifikan pada perkembangan pengetahuan arsitektur. Dalam telaah ini, sedikitnya ada dua paham yang patut dikedepankan.

\section{Strukturalisme}

Strukturalisme mengkaitkan antara realitas dengan struktur dalam yang terkandung pada seluruh aspek kehidupan manusia. Pandangan dalam teori ini terdiri dari dua sisi, yakni: struktur dan sistem. Pemikir seperti Ferdinand de Saussure dan Charles Sanders Peirce telah mengangkat strukturalisme ke dalam tataran epistemologis dan metodologis melalui konsep yang dikembangkan dengan struktur 'diadic' (langue-parole dan signifier -signified) dan 'triadic' (sign-object-interpretant).

Strukturalisme (Levis Strauss 1958) merupakan teori yang dapat mengungkap suatu sistem atau pola yang terjadi dalam satu komunitas fisik maupun non fisik. Teori ini menjelaskan bagaimana kebudayaan melalui kajian tentang perilaku, perilaku tersebut diungkap untuk mendapatkan konsep yang melatarbelakanginya. Konsep inilah yang diharapkan dapat terwujud melalui kajian secara komprehensif pengamatan perilaku termasuk adanya mitos yang berupa cerita yang kompleks yang mengungkapkan eksistensi manusia (Christomy 2002).

Mengacu pada definisi secara antropologis, Salura menyebutkan bahwa Struktur adalah sebuah bangun yang secara abstrak berkaitan satu sama lain, bangun merupakan konsep abstrak yang dapat dipahami berdasarkan tiga sifat dasar, yakni: transformasi, totalitas dan otoregulasi. Konsep struktur dapat dipandang sebagai suatu fenomena konkrit, tetapi juga ada pandangan sebagai fenomena abstrak.

\section{Tipomorfologi (Arsitektur)}

Diyakini bahwa unsur arsitektur selalu terdiri dari: pertama, fungsi sebagai satu jenis atau kumpulan aktivitas; kedua bentuk yang berupa ruang atau ruangan fisik yang mengakomodasi aktivitas; ketiga makna atau arti yang ditangkap oleh pengamatnya dari tampilan akitivitas dan bangunan tersebut. Tipomorfo yang dikemukakan oleh Quatremere de Quincy dan dikembangkan oleh Aldo Rosi. Tipologi masuk kedalam kategori klasifikasi yang dalam perjalanannya tipologi sering juga digunakan untuk mengklasifikasikan bentuk fisik atau fungsi bangunan (Salura 2010).

Argumen ini dikembangkan dan dielaborasi lanjut pada studi ini selain tipologi fisik serta fungsi bangunan, juga tipologi yang mengabstraksikan bentuk dan kegiatan fisik menjadi tipe abstrak. 
Bentuk arsitektur rumah tinggal dengan gaya kolonial di Kota Pasuruan berdasarkan teori kebudayaan yang ada di kawasan kota Pesisir Utara Jawa memiliki tipologi bentuk berdasarkan elemen wajah bangunan, ornamen, gaya dan tahun pembuatannya. Gaya yang dimaksud adalah Indische Empire Style, Voor 1900, NA 1900.

Antariksa menyebutkan bahwa tipologi merupakan studi yang berkaitan dengan tipe dari beberapa objek yang memiliki jenis yang sama. Tipologi merupakan sebuah bidang studi yang mengklasifikasikan, mengkelaskan dan mengelompokkan objek dengan ciri khas struktur formal yang sama dan kesamaan sifat dasar ke dalam tipe-tipe tertentu dengan cara memilah bentuk keragaman dan kesamaan jenis. Aspek klasifikasi berdasarkan aspekaspek/kaidah-kaidah tertentu, seperti: fungsi, bentuk maupun gaya. Sulistijowati dalam Antariksa dalam upaya mengkelaskan, mengelompokkan berdasarkan aspek fungsi, geometrik dan langgam (Antariksa 2010).

\section{Relasi dan Konsep Fungsi, Bentuk dan Makna Arsitektur Pesisir}

Sosok arsitektur di kawasan Pesisir utara Jawa terbentuk melalui berbagai konsep yang melingkupinya. Konsep sebagai bentuk representasi nilai dan unsur yang dianut oleh masyarakat kota Pesisir dalam bentuk tradisi secara turun temurun. Tradisi yang dimaksud sekaligus merupakan ekspresi bentuk percampuran nilai-nilai budaya pendatang (Cina) yang masuk dan melebur kedalam budaya lokal Jawa (Pesisir).

Arsitektur Pesisir dapat dipandang sebagai konsep arsitektur yang merupakan relasi antara fungsi, bentuk dan makna arsitektur rumah tinggal Pesisir sebagai kesatuan yang utuh dalam membentuk identitas arsitektur kota Pesisir, dengan ciri yang melekat sebagai bentuk akulturasi budaya dan memiliki nilai dan unsur yang adaptif terhadap segala perubahan. Relasi yang terjadi antara fungsi, bentuk dan makna akan membuka konsep yang ada dibelakangnya dari objek rumah tinggal di Pecinan Kampung Karangturi dan Kampung Jawa Sumber Girang, Lasem (Antariksa 2010).

\section{Konsep Bentuk sebagai Relasi Tipe Kegiatan dan Tipe Ruang (Struktur dalam Fungsi)}

Konsep fungsi yang terekspresi dalam arsitektur masyarakat kota Pesisir terlihat dari bagaimana relasi yang terkait antara 'Tipe Kegiatan dan Tipe Ruang' tersebut. Tipe-tipe ini akan menghasilkan 'Struktur Dalam Fungsi' (Fauzy 2012). Konsep fungsi inilah yang pada akhirnya akan membentuk pola dan tipe ruang, termasuk akan menentukan berbagai tipe kegiatan yang dilakukan dalam kehidupan keseharian penghuni (Tabel 1).

\section{Konsep Bentuk sebagai Relasi Tipe Wadah dan Struktur Konstruksi (Struktur dalam Bentuk)}

Konsep bentuk yang terekspresi dalam arsitektur Pesisir terlihat dari bagaimana relasi yang terkait antara 'Tipe Wadah dan Struktur-Konstruksi' tersebut. Tipe-tipe ini akan menghasilkan 'Struktur Dalam Bentuk' (Fauzy 2012). Konsep bentuk inilah yang pada akhirnya akan membentuk tipe wadah dan struktur konstruksi, termasuk yang akan menentukan berbagai tipe wadah yang terekspresi dalam kehidupan keseharian penghuni (Tabel 2).

\section{Konsep Bentuk sebagai Relasi Tipe Makna dan Tampilan Bentuk (Struktur dalam Makna)}

Konsep bentuk yang terekspresi dalam arsitektur rumah tinggal masyarakat kota Pesisir utara di kawas-

Tabel 1. Relasi Manusia Jawa (Pesisir) dengan Tipe Kegiatan dan Tipe Ruang (Struktur Dalam Fungsi)

\begin{tabular}{ccccc}
\hline No. & Relasi Manusia Jawa (Pesisir) & Tipe Kegiatan & Tipe Ruang & Struktur Dalam Fungsi \\
\hline 1. & Manusia - Tuhan & Ritual (Selamatan) & Persembahan Roh/Tuhan & Hirarki Ruang \\
2. & Manusia - Alam & Perilaku/Aktivitas & Pasrah terhadap Alam & Relasi Ruang Dalam dan Luar \\
3. & Manusia - Masyarakat & Sosialisasi & Gotong Royong & Lokasi Ruang Dalam dan Luar \\
4. & Manusia - Pribadi & Ruang untuk Kegiatan & Sesuai dengan Norma dan & Ruang Dalam dan Luar \\
& & Sehari-hari & Kearifan Lokalnya & \\
\hline
\end{tabular}

Sumber: Fauzy (2012)

Tabel 2. Relasi Manusia Jawa (Pesisir) dengan Tipe Wadah dan Struktur - Konstruksi (Struktur Dalam Bentuk)

\begin{tabular}{ccccc}
\hline No. & Relasi Manusia Jawa (Pesisir) & Tipe Wadah & Struktur dan Konstruksi & Struktur Dalam Bentuk \\
\hline 1. & Manusia - Tuhan & Sentong Tengah & Kegiatan Ritual & Posisi Ruang \\
2. & Manusia - Alam & Ragam Bentuk & Kegiatan Produksi & Bentuk Bangunan \\
3. & Manusia - Masyarakat & Sosialisasi & Kegiatan Sosial & Bentuk Ruang \\
4. & Manusia - Pribadi & Kegiatan Sehari-hari & Kegiatan Sehari-hari & Tatanan Ruang \\
\hline
\end{tabular}


Tabel 3. Relasi Manusia Jawa (Pesisir) dengan Tipe Makna dan Tampilan Bentuk (Struktur Dalam Makna)

\begin{tabular}{ccccc}
\hline No. & $\begin{array}{c}\text { Relasi Konsep } \\
\text { Manusia Jawa (Pesisiran) }\end{array}$ & Tipe Makna & Tampilan Bentuk & Struktur Dalam Makna \\
\hline 1. & Manusia - Tuhan & Religi/kepercayaan & Struktur - tata letak ruang & Relasi ketuhanan \\
2. & Manusia - Alam & tindakan & Penggunaan material & Relasi alam \\
3. & Manusia - Masyarakat & Gotong royong & Kebersamaan (sarana dan prasarana publik) & Relasi kemanusiaan \\
4. & Manusia - Pribadi & Status sosial & Penggunaan ragam bentuk & Relasi individu/pribadi \\
\hline Sumber: Fauzy (2012) & & &
\end{tabular}

Sumber: Fauzy (2012)

an Jawa Timur terlihat dari bagaimana relasi yang terkait antara 'Tipe Makna dan Tampilan Bentuk' tersebut. Tipe-tipe ini akan menghasilkan 'Struktur Dalam Makna' (Fauzy 2012). Merujuk pada relasi yang terjadi, makna inilah yang akan menentukan bagaimana tipe makna dan tampilan bentuk yang merupakan representasi dari tipe yang terwujud dalam kehidupan keseharian penghuni (Tabel 3).

\section{ARSITEKTUR PESISIR UTARA JAWA TIMUR DI LASEM}

Arsitektur Pesisir utara Jawa di kota Lasem merupakan bentuk lingkungan binaan yang terbentuk melalui proses percampuran berbagai budaya yang berlangsung cukup lama, bentuk percampuran ini dikenal dengan pengertian Akulturasi Budaya. Budaya pendatang Cina ditengarai mempengaruhi terbentuknya arsitektur masyarakat kota Pesisir yang terekspresi pada sosok arsitekturnya.

\section{Pecinan di Kampung Karangturi dan Kampung Jawa Sumber Girang, Lasem}

Pecinan di kampung Karangturi dipengaruhi oleh nilai-nilai budaya Cina dan merupakan kampung yang dihuni oleh komunitas masyarakat etnis Cina Jawa Pesisir, keberadaan kampung ini dengan bangunan-bangunan yang dipengaruhi oleh Arsitektur etnis Cina sebagai patron. Gubahan arsitekturnya dengan beberapa ragam bentuk perpaduan arsitektur Jawa dan Cina. Kampung Sumber Girang memiliki pengaruh budaya Cina berdasarkan fenomena di Pesisir Utara kawasan Jawa Timur (Fauzy 2012).

Kampung Sumber Girang, Lasem yang merupakan kawasan periferi Pecinan sebagai kampung Jawa tumbuh mandiri dengan bentukan arsitekturnya sebagai klien. Kampung ini berada di kawasan pusat kota Lasem yang merupakan kawasan areal perkampungan rumah etnis Jawa. Bentuk-bentuk arsitekturnya dipengaruhi oleh pola bentuk arsitektur Cina.

\section{Kasus Studi 1: Arsitektur Rumah Tinggal Ibu Untari di Pecinan Kampung Karangturi, Lasem}

Rumah tinggal sebagai objek arsitektur memiliki ciri dan karakteristik unsur-unsur budaya etnis Cina. Berdasarkan fenomena masyarakat kota Pesisir di kawasan Utara Jawa Timur, arsitektur rumah tinggal di kampung Sumber Girang, Lasem yang merupakan kawasan periferi Pecinan Kampung Karangturi. Rumah ini memiliki karakteristik spesifik, bentuk arsitekturnya berlanggam arsitektur dan budaya etnis Cina.

Susunan ruang pada rumah tinggal di Kampung Karangturi memiliki susunan ruang yang simetri dan ruang terbagi menjadi empat area, yakni area teras, ruang tamu/keluarga, ruang tidur dan ruang servis/ dapur. Susunan ruang ini mengingatkan pada bentuk arsitektur Cina pada umumnya yang memberikan kesan formal pada gubahan ruangnya serta ada kejelasan pada pembagian ruangnya.

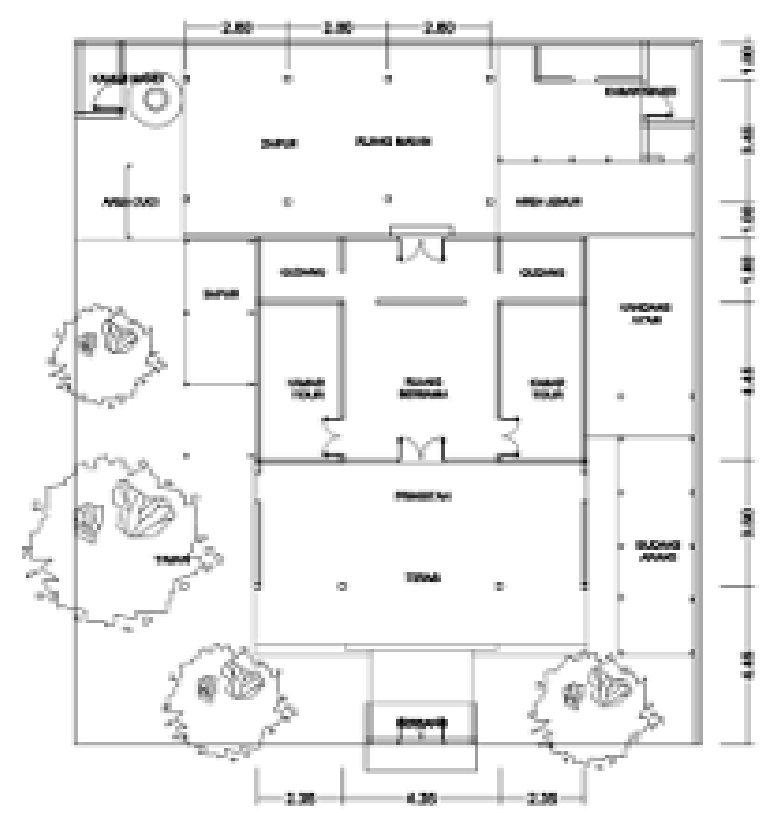

Gambar 1. Denah Arsitektur Rumah Tinggal Ibu Untari di Pecinan Kampung Karangturi, Lasem 
Bentuk atap dengan menggunakan tipe pelana menunjukkan pada bentukan arsitektur Cina, bentuk atap ini didukung dengan sistem konstruksi atap dengan kuda-kuda tipe konstruksi Cina yang menumpu pada kolom dan balok terlihat juga pada sistem kolom pendukung strukturnya. Seluruh struktur, konstruksi dan dinding pengisinya menggunakan material kayu yang mengekspresikan bentuk arsitektur tradisional, seperti halnya bangunan tradisional Jawa lainnya (Ilustrasi 1).

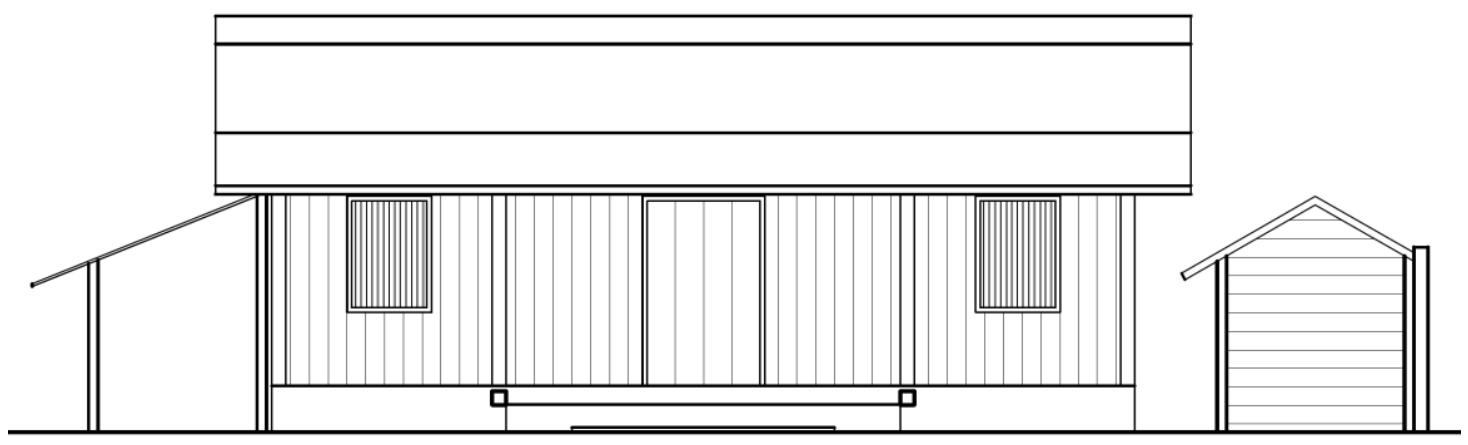

Gambar 2. Tampak Depan Arsitektur Rumah Tinggal Ibu Untari di Pecinan Kampung Karangturi, Lasem

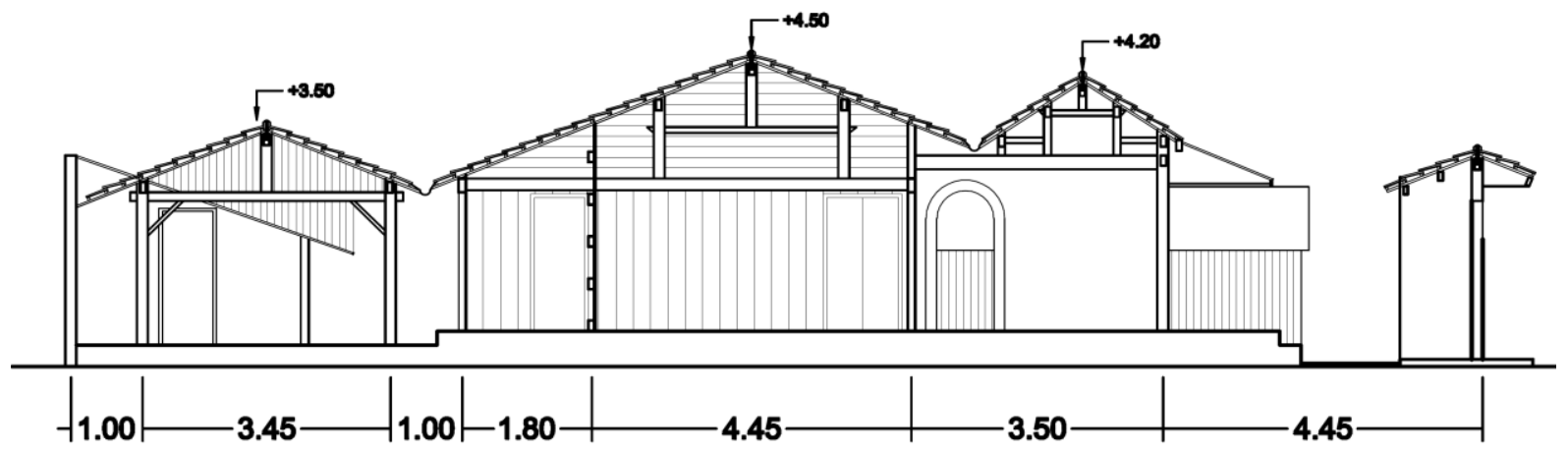

Gambar 3. Potongan Melintang Arsitektur Rumah Tinggal Ibu Untari di Pecinan Kampung Karangturi, Lasem

Ilustrasi 1. Sosok Arsitektur Rumah Tinggal Ibu Untari di Pecinan Kampung Karangturi, Lasem

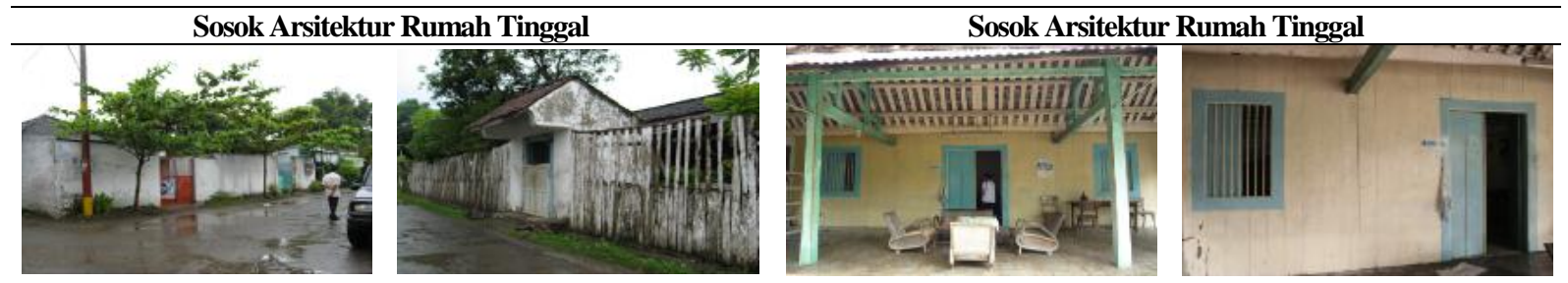

Gambar 1, 2. Ekspresi bangunan dari bagian luar bangunan menun- Gambar 3, 4. Bagian teras depan dan pintu masuk utama (dobel) jukkan karakteristik spesifik sebagai bangunan rumah Cina dengan memperlihatkan karakteristik arsitektur Cina, bagian-bagian bangundominansi dinding benteng yang melingkupi seluruh bangunan an dari elemen tersebut mempertegas ekspresi bentuk simetri dengan dengan satu gerbang utama dibagian tengah.
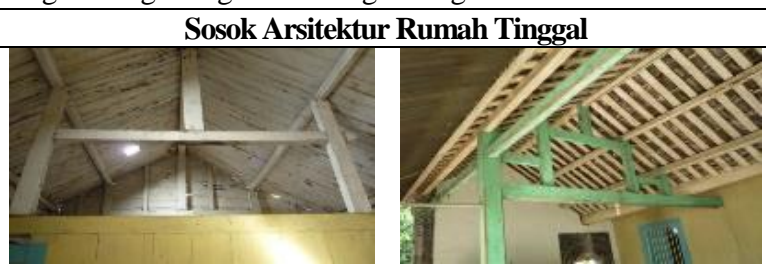
sumbu yang terlihat dari arah sirkulasi masuk.

Gambar 5, 6. Konstruksi penumpu atap rumah Cina ini dengan Gambar 7, 8. Ruang belakang dan servis berada pada bagian belapenyelesaian bentuk konstruksi yang biasa diterapkan pada rumah- kang bangunan utama dengan area yang cukup leluasa dan agak rumah Cina, dengan sistem tumpuan pada tiang disisi depan dan terbuka berhadapan dengan ruang terbuka pada sisi belakangnya. belakangnya. 


\section{Kasus Studi 2: Arsitektur Rumah Tinggal Bapak Soleh di Kampung Sumber Girang, Lasem}

Rumah tinggal sebagai objek arsitektur memiliki ciri dan karakteristik unsur-unsur budaya etnis Cina. Berdasarkan fenomena masyarakat kota Pesisir yang terjadi di kawasan Utara Jawa Timur, yakni arsitektur rumah tinggal yang berada di kampung Sumber Girang, Lasem yang merupakan periferi kawasan Pecinan (Kampung Karangturi). Rumah ini memiliki karakteristik spesifik, bentuk arsitekturnya dipengaruhi oleh langgam arsitektur dan budaya etnis Cina.

Susunan ruang pada rumah tinggal di Kampung Sumber Girang memiliki kesamaan dengan pola bangunan arsitektur rumah di Pecinan Kampung Karangturi, yakni dengan susunan ruang yang simetri dan ruang terbagi menjadi empat area, yakni area teras, ruang tamu/keluarga, ruang tidur dan ruang servis/dapur. Susunan ini mengingatkan pada bentuk arsitektur Cina pada umumnya yang memberikan kesan formal pada gubahan ruangnya serta ada kejelasan pada pembagian ruangnya.

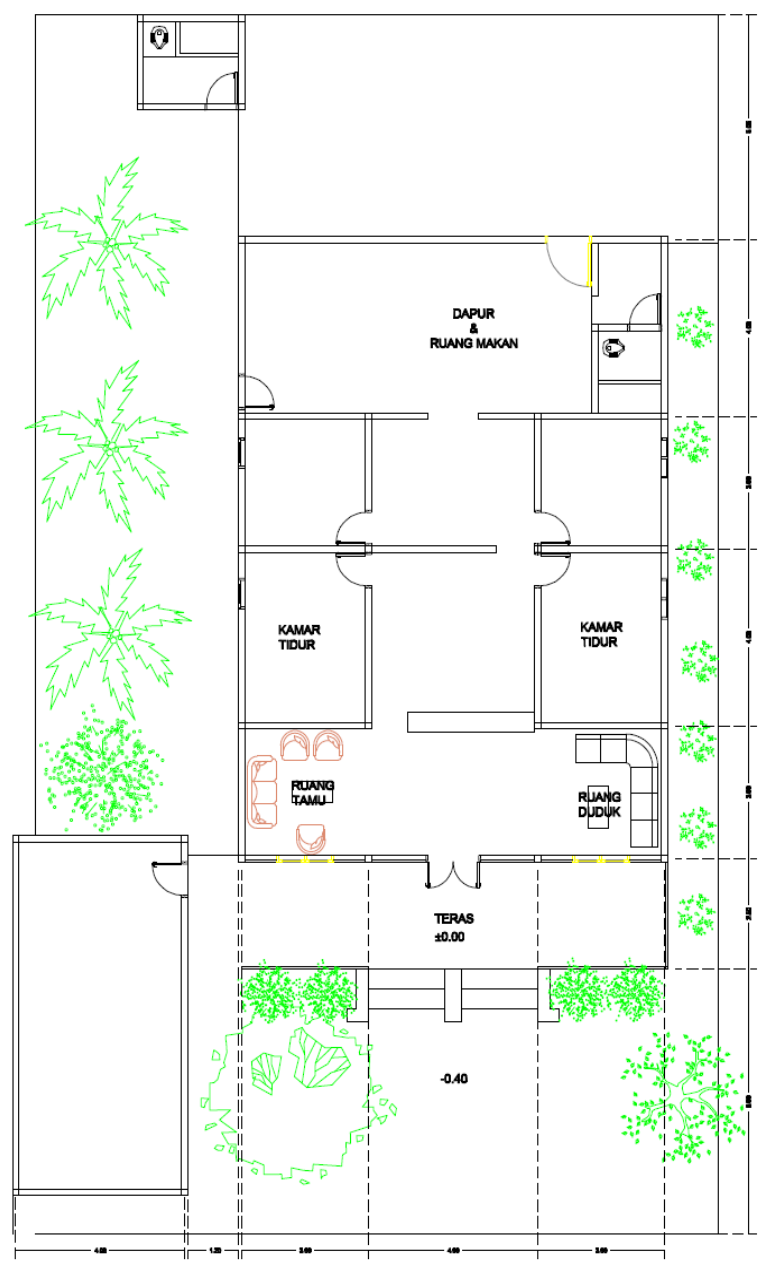

Gambar 4. Denah Arsitektur rumah tinggal Bapak Soleh di Kampung Sumber Girang, Lasem
Bentuk atap dengan menggunakan tipe pelana menunjukkan pada bentukan arsitektur Jawa, bentuk atap ini didukung dengan sistem konstruksi atap dengan kuda kuda yang menumpu pada kolom dan balok. Seluruh struktur, konstruksi dan dinding pengisinya menggunakan material kayu yang mengekspresikan bentuk arsitektur tradisional, seperti halnya bangunan tradisional Jawa lainnya.

Bentuk-bentuk elemen dan ornamen yang diterapkan pada arsitektur rumah tinggal ini dipengaruhi oleh unsur-unsur budaya dan arsitektur Cina, bentuk tersebut mencakup detail-detail konstruksi atap, penggunaan badukan di teras depan, motif railing teras dan lainnya. Bentuk tersebut hanya memberikan karakter yang sifatnya elementer dan pada akhirnya juga mewarnai pembentukan identitas arsitektur Pesisir Utara di kawasan Jawa Timur.

Ekspresi bangunan dari tampilan depan bangunan menunjukkan gubahan bentuk simetri, terlihat pada susunan ruang, pintu ditengah dan kedua jendela yang berada disisi kanan dan kiri, empat tiang. Struktur dan konstruksi kayu diperlihatkan sebagai ekspresi pola bangunan di kawasan pecinan. Susunan ini mempertegas konsep dualitas menurut pandangan sikap manusia Jawa (Ilustrasi 2).

Relasi konsep manusia Jawa dengan Tuhan, alam, masyarakat dan pribadi terhadap konsep fungsi, bentuk dan makna yang terjadi pada arsitektur lokal Pesisir Utara di kawasan Jawa Timur akan membentuk kebertahanan dalam menghadapi pengaruh budaya dan arsitektur pendatang. Arsitektur rumah tinggal di kampung Sumber Girang memiliki beberapa unsur bentukan arsitektur yang tetap bertahan karena unsur budaya Jawa yang cukup dominan pada tipe bentuk atap, pola ruang utama dan sistem struktur konstruksi bangunannya, sedangkan unsur yang berubah (pengaruh budaya Cina) pada tipe pembatas kapling lahan rumah, penggunaan ornamentasi pada bangunannya (Tabel 4).

Kearifan lokal yang terbentuk pada arsitektur rumah tinggal Bapak Soleh di kampung Sumber Girang karena kuatnya nilai-nilai tradisi lokal dan konsep budaya Jawa berdasarkan tradisi dan relasi manusia Jawa dengan Tuhan, alam, sosial dan pribadi secara turun menurun, sehingga terjadinya pengaruh bentuk-bentuk arsitektur tersebut terbatas pada tipe dan pola bentuk elementernya.

\section{KESIMPULAN}

Dari hasil studi ini dapat disimpulkan bahwa: Pertama, Bentuk arsitektur lokal di kawasan Pesisir Utara Jawa Timur merupakan arsitektur lokal yang sangat dipengaruhi oleh nilai-nilai etnis budaya Cina. 


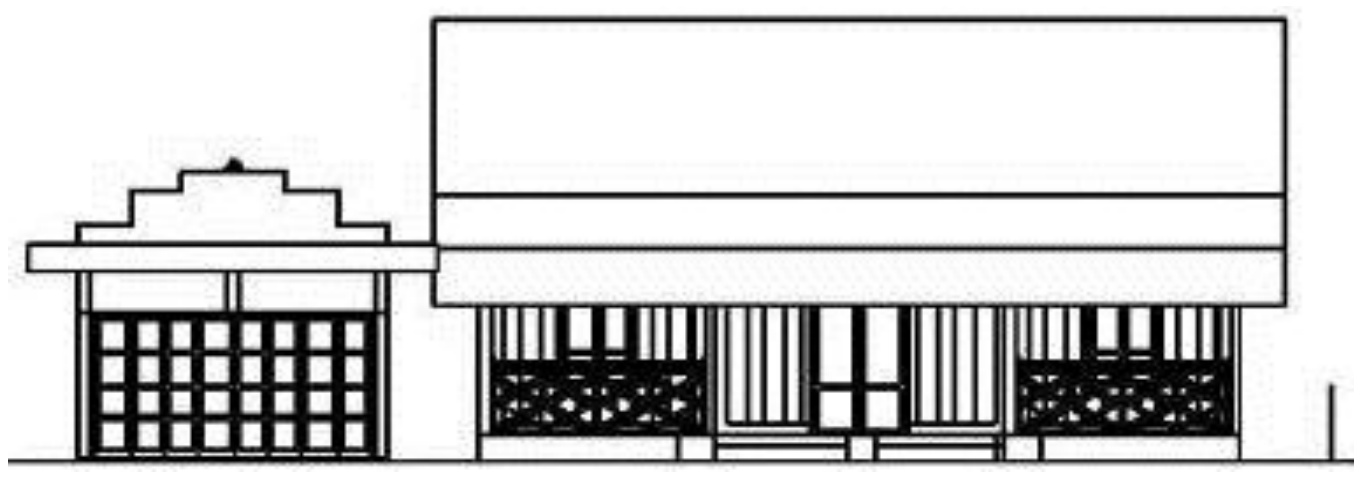

Gambar 5. Tampak Depan Arsitektur rumah tinggal Bapak Soleh di Kampung Sumber Girang, Lasem

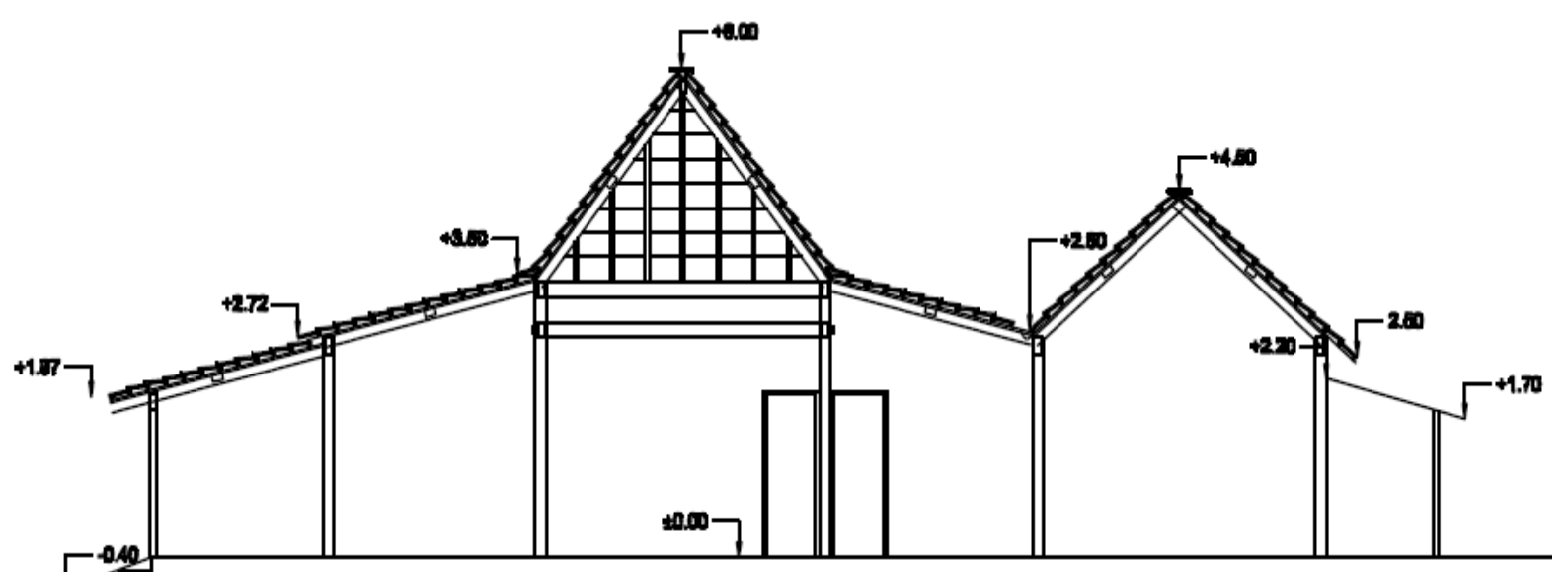

Gambar 6. Potongan Melintang Arsitektur rumah tinggal Bapak Soleh di Kampung Sumber Girang, Lasem

Ilustrasi 2. Sosok Arsitektur Rumah Tinggal Bapak Soleh di Kampung Sumber Girang, Lasem

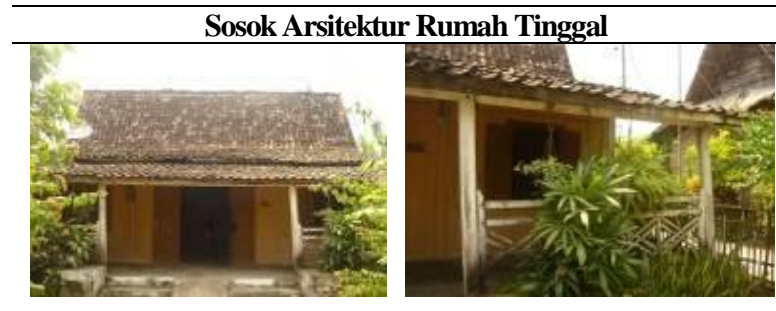

Gambar 1, 2. Tampilan depan bangunan menunjukkan karakter bentuk yang simetri dengan pembagian dua jendela kiri kanan dan pintu utama di tengah dan teras depan. Pembagian elemen fasade juga mewarnai karakteristik arsitektur Jawa.
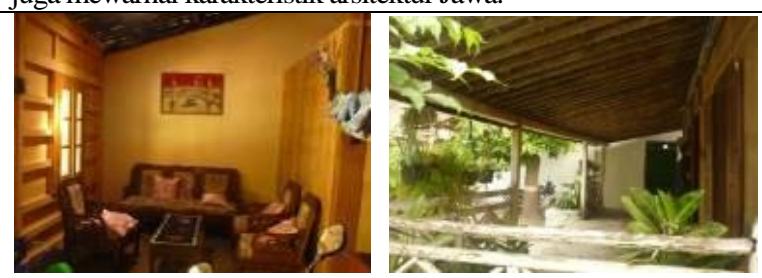

Gambar 5, 6. Ruang depan (tamu) menunjukkan hirarki area utama dan teras depan berfungsi sebagai ruang penerima utama atau ruang peralihan. Berdasarkan susunan ruang yang ada menunjukkan hirarki yang tegas pada bangunan tersebut.

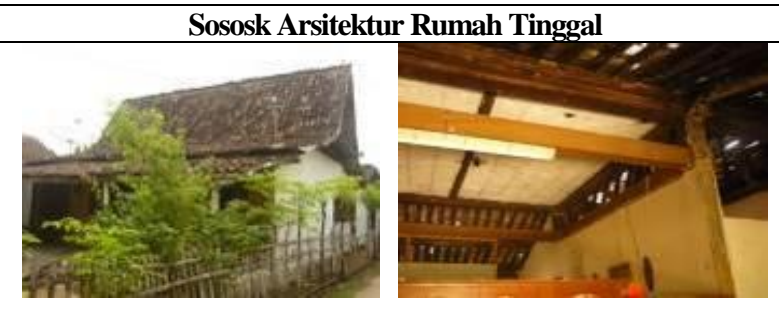

Gambar 3, 4. Tampak samping depan menunjukkan bentukan atap Jawa dan tepi bangunan dengan dinding kayu dan konstruksi ruang tengah dengan susunan kolom dan balok kayu.
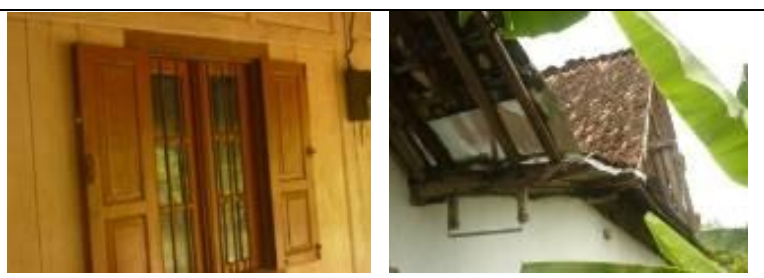

Gambar 7, 8. Jendela samping depan bangunan menunjukkan adanya kejelasan bukaan pada bagian fasade bangunan depan dan teritis samping merupakan penyelesaian bagian tepi atap. Bagian dari bentuk atap ini menunjukkan ekspresi yang dipengaruhi oleh unsur bentuk atap rumah Cina. 
Arsitektur rumah di Pecinan kampung KarangturiLasem merupakan arsitektur komunitas etnis Cina dengan gaya arsitekturnya yang terlihat pada ekspresi bentuk-bentuk dan susunan ruang yang simetri berdasarkan fungsinya.

Kedua, Arsitektur Pesisir dipandang sebagai konsep arsitektur yang merupakan relasi antara fungsi, bentuk dan makna arsitektur rumah tinggal Pesisir sebagai kesatuan yang utuh dalam membentuk identitas arsitektur kota Pesisir, dengan ciri yang melekat sebagai bentuk akulturasi budaya dan memiliki nilai dan unsur yang adaptif terhadap segala perubahan. Relasi yang terjadi antara fungsi, bentuk dan makna akan membuka konsep yang ada dibelakangnya dari objek rumah tinggal di Pecinan Kampung Karangturi dan Kampung Jawa Sumber Girang, Lasem.

Ketiga, Arsitektur rumah tinggal di Kampung Jawa Sumber Girang, Lasem terekspresi dalam wujud tipe bentuk, pola bentuk-ruang dan tatanannya serta struktur dan konstruksi yang memiliki karakteristik sebagai arsitektur rumah Jawa. Ada beberapa unsur bentukan arsitektur yang tetap bertahan seperti: tipe bentuk atap, pola ruang utama dan sistem struktur konstruksi bangunannya sebagai struktur dalam, sedangkan unsur dan gubahan yang berubah karena pengaruh budaya etnis Cina terletak pada tipe pembatas kavling lahan rumah, penggunaan ornamentasi pada bangunannya sebagai struktur permukaan.

Keempat, Untuk memahami relasi konsep fungsi, bentuk dan makna arsitektur pesisir dapat diungkap melalui telaah relasi konsep sikap manusia Jawa dengan tipe fungsi, bentuk dan makna yang melingkupinya, sehingga menghasilkan struktur permukaan dan struktur dalamnya.

\section{DAFTAR PUSTAKA}

Adimihardja, Kusnaka \& Purnama Salura. (2004). Arsitektur Dalam Bingkai Kebudayaan. Foris, Bandung.

Antariksa. (2010). Menuju Pendidikan Arsitektur Indonesia Berbasis Riset (Seminar Nasional Metode Riset Dalam Arsitektur). Udayana University Press, Bali.

Christomy, Tommy. (2002). Indonesia: Tanda Yang Retak. Wedatana Widya Sastra, Jakarta.

Endraswara, Suwardi. (2010). Falsafah Hidup Jawa, Menggali Mutiara Kebijakan dari Intisari Filsafat Kejawen. PT. Bhuana Ilmu Populer (Kompas Gramedia Group), Jakarta.

Fauzy, Bachtiar. (2012). Kearifan Lokal Dalam Konsep Arsitektur Rumah Tinggal Masyarakat Kota Pesisir Utara Jawa, Kasus Studi: Rumah Tinggal di Desa Sumber Girang-Lasem. Penelitian Lembaga Penelitian dan Pengabdian Masyarakat, Unpar, Bandung.

Lombard, Denys. (1996). Nusa Jawa: Silang Budaya, Kajian Sejarah Terpadu, Bagian 1: Batas Batas Pembaratan. Gramedia Pustaka Utama, Jakarta.

Pratiwo. (2010). Arsitektur Tradisional Tionghoa dan Perkembangan Kota. Ombak, Yogyakarta.

Salura, Purnama. (2010). Arsitektur Yang Membodohkan. Cipta Sastra Salura, Bandung.

Vickers, Adrian. (2009). Peradaban Pesisir: Menuju Sejarah Budaya Asia Tenggara. Pustaka Larasan, Udayana University Press, Denpasar. 